Palchuk Petro,

Phd in Law, Associate Prof., Dean of International Trade and Law Faculty, Kyiv National University of Trade and Economics, 19, Kyoto str., Kyiv, 02156, Ukraine

ORCID: 0000-0002-1399-6543

Researcher ID: M-3178-2016

\title{
ELECTRONIC CORPORATION REGISTRY AS A COMPONENT OF CORPORATE PROTECTION RIGHTS
}

The article deals with the issues of keeping electronic registers as a component of state registration of commercial legal entities (corporations). The problems of keeping electronic registers have been identified and the directions for improving the legislation have been identified.

Keywords: applicant, state registration, electronic register, state registrar, access to state register.

Пальчук П. Електронний реєстр корпорацій як складова захисту корпоративних прав.

В статті розглядаються питання ведення електронних реєстрів як складової державної реєстрації комериійних юридичних осіб (корпорацій). Визначено коло проблем щуодо ведення електронних реєстрів та визначені напрями удосконалення законодавства.

Ключові слова: заявник, державна реєстрачія, електронний реєстр, державний реєстратор, доступ до державного реєстру.

Relevance of research topic. Within current conditions of development of the corporate sector in Ukraine, the main task of public authorities is to establish attractive investment environment to provide legal guarantees to investors in preserving their assets. First of all, when deciding to set up a corporation, founders, such as limited liability companies, should legitimize the legal entity and implement proper corporate governance for that corporation. But the corporate rights owners to be should understand the peculiarities of starting a business in Ukraine, the role of the state as a regulator of corporate relations, and the involvement of other participants into corporate relations within the activities of corporations and the legal mechanisms for saving and protection of corporate rights.

Formulation of the problem. Proper legal regulation of the whole set of legal relationships in regards to the procedures for state registration of corporations and the 
maintenance of the Unified State Register of Legal Entities, Individuals that is Entrepreneurs and Public Formations (hereinafter referred to as the Unified State Register) is crucial for owners of corporate rights and other participants in corporate legal relations. Without proper standardization of state registration procedures and inclusion of relevant records into the state register of the corporation and related persons is impossible for proper corporate governance in the corporation and protection of the rights of the participants (shareholders), which are prerequisites for raising capital in the corporate sector of the economy. At the same time, the protection of corporate rights of members of corporations (commercial legal entities) from raider seizures is the main task of the state in the person of authorized bodies and officials.

Analysis of recent researches and publications. The issues of maintaining an electronic register on the creation and further functioning of commercial legal entities (corporations) have been the subject of research by a significant number of scholars. In particular, the problems of maintaining the Unified State Register as a component of the registration system of corporations, electronic registers were generally considered by O.M. Vinnyk, N.M. Dyakovych, O. R. Kibenko, I. V. Lukach, I. V.Spasibo-Fateeva and other scientists.

Presentaton of the main material. Despite the fact that in today's Ukraine corporations are quite successful in conducting business activities, the phenomenon of unlawful take over of corporate control over such organizations by third parties remain spread out, thus violating the rights of investors. Adequate protection of the rights of investors who have invested their assets into the corporate rights of Ukrainian commercial entities is a determinant of business confidence for the state, and serves as an indicator for attracting assets of national and foreign investors into the economy.

The current legislation of Ukraine, which regulates the activity of legal entities in the whole, and commercial legal entities in particular, has undergone significant changes in recent period. In its turn, corporate law, including the entry of relevant data in state registers, first of all, of the Unified State Register, needs further revision. It should be emphasized that a large number of registers are kept in Ukraine, which go beyond the limits of their own economic activity, as well as directly or indirectly affect the activities of corporations and other entities. However, through the prism of corporate rights protection, the decisive importanceis being to maintain theUnified State Register of Legal Entities, Individuals - Entrepreneurs and Public Formations [8]. The general requirements for maintaining this register are defined by the Law of Ukraine «On State Registration of Legal Entities, Individuals - Entrepreneurs and Public Formations» [5]. The rules of the current Law on State Registration generally cover three different groups of relationships:

- in regards to the state registration of a newly established legal entity;

- amending the articles of association (founding agreement) and the Unified State Register of Legal Entities, Individuals - Entrepreneurs and Public Formations;

- the relationship related to the termination of the legal entity. 
The information that is entered into the register of corporations reflects the principles of its creation, management features and identifies the person (s) - owners of corporate rights, etc. Therefore, the issue of proper keeping of registers for corporations and members of such corporations is overwhelmingfor the proper functioning of this type of legal entities and makes it impossible for corporate control raider interception [1, p. 53].

State registration as part of the legitimation of corporations and their activities by the state is intended to provide information to other legal entities, as well as to provide investors with a guarantee of the legality of their activities in whole and in the part of certain registration actions. It should be understood that relations in regards to the registration of a legal entity and the maintenance of the Unified State Register are governed by the norms of various branches of the law, including administrative, civil, economic featuring their complex nature. In particular, the state represented by the governing authorized bodies and persons carrying out the necessary for registration actions, persons creating legal entities have their own legal purpose, their own goals. However, theirs common featuresare of that the implementation of state registration on the basis of legality and the proper procedure for maintaining the Unified State Register is in the interests of all participants in the relationship.

One of the issues of today in the sphere of corporate relations regulation that are relevant is the save and protection of corporate rights of thecorporations' members. The most frequently mentioned issues are protection of management and legitimate interests of participants of corporate legal relations from raider take overs. Despite the fact that the concept of «raid» as a general legal category is absent in the legislation of Ukraine in the overwhelming majority, it means unlawful activities to intercept control of certain property through the lens of research on the corporate rights of participants of commercial legal entities.

For today the main registration actions have their fixation in the Unified State Register, the data of which is reliable and open for public. Thus, as for the legal entity, the founders (members of the legal entity), other interested persons according to the information of the state register confirmed by the state are being prerequisite for committing certain legally significant actions of property and non-property nature. The legislator determines that the transfer of corporate control or corporate rights to a corporation implies the obligation to take certain actions in the field of amendments to the Unified State Register and other related registration actions, as well as to register changes into the constituent documents of the corporation.

On the legislative level the procedure for maintaining the Unified State Register is determined by the Law of Ukraine «On State Registration of Legal Entities, Individuals - Entrepreneurs and Public Formations», approved by the order of the Ministry of Justice of Ukraine dated February 9, 2016 № 359/5 [3].

M. M. Dyakovych, exploring the problems of notarial protection and save of corporate rights of the founders (participants) of limited liability companies, identified certain problems in this area. In particular, the simplification of the procedure for registration of documents of legal entities that are required for certain registration 
activities did not always achieve the intended result. As the consequence in the field of corporate law the reverse process is taking place, namely, the fake and falsification of documents, on the basis of which certain registration actions are carried out and the information is entered into the Unified State Register [2, p. 65].

The measures envisaged by the Decree of the President of Ukraine «On Measures to Raiding Counteract» are aimed at minimizing such actions. In particular, the President Decree stipulates the obligation of notarization of contracts subject to the alienation of a share in the authorized capital of a particular legal entity, except for contracts created on the portal of electronic services of legal entities, individualsentrepreneurs and public entities signed by using qualified electronic signatures. This provision of the President Decree allows us to draw a number of conclusions. The first conclusion is that the problem of maintaining the Unified State Register has become important because of the non-compliance (violation) of corporate rights of individuals and legal entities. Secondly, in order to protect legitimate interests of the owners of corporate rights the requirement for notarization of contracts for the alienation of corporate rights is established, and it is subject to notarial certificate, and recorded into the Unified State Register. In this direction, the Ministry of Justice of Ukraine is also spreading out its efforts according tothe order of July 18, 2019 «On measures to strengthen the preservation and protection of data of the Unified State Register of Real Estate Rights, the Unified State Register of Legal Entities, Individual-Entrepreneurs and Public Formations» No. 790/33761 provides the verification of all persons having access to the Unified State Register [6].

Unlike the previous period, when records into the Unified State Register did not require compliance with special requirements, there was a widespread violation of participants' corporate rights. In order to minimize the negative manifestations regarding the maintenance of the Unified State Register, in 2016 the Law of Ukraine «On Amendments to Certain Legislative Acts on Improvement of State Registration of Real Estate Rights and Property Rights Protection» of October 06, 2016 No. 1666-VII [4] was adopted. This law establishes the requirements for the order of submission of documents to the state registrar and the procedure for their notarization, if provided by the legislation. However, these measures reduced the number of negative manifestations regarding the maintenance of the Unified State Register, but did not solve all the problematic issues. Nevertheless, to date these issues are legislatively regulated, but it remains necessary to eliminate all contradictions in current legislation regarding the maintenance of electronic state registers and the Unified State Register in accordance with the principles of the rule of law, protection of property rights and restoration of violated rights.

Conclusion. In the whole the rules and norms of the current legislation of Ukraine allow to protect the corporate rights of large and small investors, to regulate the issues of corporate governance of corporations and promote their sustainable development. Nevertheless, a number of issues regarding the proper protection of the rights of members of corporations remain, namely the corporations themselves. Therefore, the activity of public authorities in the field of protection of corporate 
property, enforcement of corporate governance in different types of corporations should be reviewed in the part of recording information into the Unified State Register exclusively in the form and in the way that reflects the will of the owners of corporate rights and is not about allowing to putinformation into the register that directly or indirectly violates the rights of corporate investment entities.

\section{REFERENCES}

1. Vinnyk O. M. Electronic component in corporate legal relationships. Corporate Law of Ukraine and European Countries: Issues on the Theory and Practice: Collection of Scientific Papers on the Materials of the $\mathrm{XV}^{\text {th }}$ International Scientific and Practical Conference (6-7 October 2017, Ivano-Frankivsk) / Private Law and Entrepreneurial Research Institute named after F. G. Burchak of the National Academy of Science of Ukraine; after editing by the Doctor of Sciences, Academician of the National Academy of Sciences of Ukraine V.V. Luts. - Ivano-Frankivsk, 2017. p. 49-53.

2. Dyakovych M. M. Notarial protection and preservation of corporate rights of the founders (participants) of a limited liability company // Comparative-analytical law. 2016. № 4. With 65-67.

3. The procedure for state registration of legal entities, individualsentrepreneurs and public organizations that do not have the status of legal entity, which was approved by the order of the Ministry of Justice on February 9, 2016 No. 359/5. URL: https://zakon.rada.gov.ua/laws/show/z0200-16. (accessed August 01, 2019).

4. On Amendments to Some Legislative Acts on Improvement of State Registration of Real Estate Rights and Property Rights Protection: Law of Ukraine of October 6, 2016 No. 1666-VII. URL: https://zakon.rada.gov.ua/laws/show/1666-19. (accessed August 01, 2019).

5. On state registration of legal entities, individuals-entrepreneurs and public entities: Law of Ukraine dated May 15, 2003 No. 755-IV. URL: https://zakon.rada.gov.ua/ laws/show/755-15. (accessed August 01, 2019).

6. On measures to enhance the preservation and protection of data of the State Register of Real Estate Rights, the Unified State Register of Legal Entities, Entrepreneurs and Public Formations: Order of the Ministry of Justice of Ukraine dated July 18, 2019 No. 790/33761. URL: https://zakon.rada.gov.ua/laws/main/z0790-19. (accessed August 01, 2019).

7. On measures to counter the raiding: President Decree of July 22, 2019 No. 542/2019. URL: https://zakon.rada.gov.ua/laws/main/542/2019. (accessed August 01, 2019).

8. On some measures to improve access to electronic services by individuals and legal entities: President Decree of July 29, 2019 No. 558/2019 URL: https://zakon.rada.gov.ua/laws/main/558/2019. (accessed August 01, 2019). 